\title{
BUILT ENVIRONMENT IMPACT TO MICROCLIMATE (AIR TEMPERATURE)
}

\author{
Syaiful Muazir ${ }^{*}$, Lestari $^{2}$ \\ ${ }^{1,2}$ Department of Architecture, Engineering Faculty, Universitas Tanjungpura \\ Jl. Prof. Dr. H Hadari Nawawi, Pontianak, Indonesia \\ *Corresponding author; Email: syaifulmuazir@teknik.untan.ac.id
}

\begin{abstract}
In step with economic growth, Pontianak City continues developing its physical development. From an environmental perspective, physical development that does not pay attention to the environment may make air temperature rise and create inconvenience to human. The purpose of this study is to evaluate the indications/tendency in the built environmental elements that have the possibility of influencing the microclimate in the urban center or trade area in Pontianak City. Built environmental elements such as building density, building height, materials, etc. are described and then simulated towards the existing atmospheric condition such as temperature, humidity, solar radiation, cloud cover, and others. The simulations used three-dimensional software ENVI_MET version 4. From findings, it can be seen that atmospheric condition influences are generally still dominant rather than built environment characteristics. However, the characteristics (condition) of the built environment are related and influence each other, but are not a dominant determinant of how area temperature is rising or falls. Several built environment elements that might affect air temperature within the study area are (1) road material (Asphalt), (2) building density and shadowing, (3) the amount of vegetation, (4) the direction of wind, and (5) distance from heat source (e.g. road material/asphalt).
\end{abstract}

Keywords: Microclimate; temperature; trade area; impact; Pontianak.

\section{INTRODUCTION}

Pontianak City is the capital city of West Kalimantan in Kalimantan (Borneo) Island, which has an area of 108.82 square kilometers with a population reaching 650,000 people (2017). Geographically, Pontianak City also has its uniqueness, which is crossed by the Equator line at 0 degrees of latitude. As the economy continues to grow to around 6\% (Antara news, 2018), the economy in Pontianak City continues to "pulse" and has an impact on many sectors. Some sectors that support the economic growth in Pontianak City are transportation and communication, trade, hotels and restaurants, and construction. In the direction of the City's spatial plan, Pontianak City space is managed to aim to create the leading trading and service city in Kalimantan Island. To ensure that, the government of Pontianak City formulates a policy by developing trade and service areas to be distributed equally in the centers of urban activities with a strategy or supported by providing open space, infrastructure, tourism, connectivity, formal-informal synergy, and revitalization. Allotment of trade and services is divided into several types. In fact, trade and service allocation areas are divided into several types, namely: (1) traditional markets, (2) shopping centers, and (3) modern shops.

The development in Pontianak City can be seen through continued physical development; in the service sector, until 2018, there are at least 46 various star hotels in Pontianak City, with a total of 4,160 rooms (Pemred, 2018). Besides, the presence of modern retails also continues to grow, even in remote areas. At least in the last 15 years (nationally), the development of modern retail was very extraordinary (thetanjungpuratimes, 2018). Retails are not only concentrated in big cities in Indonesia, but also have penetrated the remote areas. With limited land, the development in Pontianak City also began to be built vertically. Because of the limited land, some hotels have been built vertically, creating new models and patterns in the trade area, and this will have an impact on the physical and social conditions.

Physical development may have positive and negative effects. The positive impact of development can be in the form of high income, good infrastructure, and excellent public services. While according to Bhatta (2010), urban area growth and population distribution that occur may result in several consequences, including slum, increased service costs, rising environmental temperatures and poor air quality. From an environmental perspective, urban development that does not pay attention to the environmental quality may make the air temperature rise. Viewed from a smaller scale in urban areas, one area can form a microclimate, which is a specific climate from one area that can affect the comfort of the surrounding. According to Erell et al., (2011), microclimate in urban studies can be formed based on several elements such as temperature, wind movement, sun radiation, the proportion of buildings/ spaces, materials, and vegetation. 
Physical growth (especially buildings) may bring various benefits as well as negative impacts. Buildings are included as a system that is connected to the climate outside the building and the climate inside it (for the convenience). Outside the building, the arrangement of buildings interacts directly with the local microclimate system, such as wind, sunlight, vegetation, and air temperature. In the recent years, researchers have begun to focus on building configurations that are adaptive to the local climate to be more sustainable and environmentally friendly. For that reason, it is necessary to consider evaluating the built environment (physically) in a series of urban studies.

Building configuration evaluation in its distribution in one area that has an impact on local microclimate may be done by investigating several aspects, such as temperature, wind movement, radiation, the proportion of buildings/spaces, materials, and vegetation. Microclimate can gradually turn to bad condition, creating uncomfortable situation for the environment and human if physical development is not planned in such a way. Therefore, an evaluation process and adaptive approach can be carried out to find ideal conditions that have benefit to the environment and human comfort.

The purpose of this paper is to evaluate the indications or tendency of the microclimate elements in the trade and service areas in Pontianak City, especially at Gajah Mada Street. Microclimate elements that will be simulated are the air temperature based on the consideration of physical environment configuration such as building density, building orientation, building material, shadowing, building envelope, building height, and vegetation. The results of this paper are able to explain the tendency of the microclimate conditions against physical environment configuration in trade and services areas located in the developing urban center.

\section{SNAPSHOOT OF LITERATURE REVIEW}

The relationship between development and its effects on microclimate has been a concern recently. To reduce climate change and the impact of global warming in cities, urban planning and design studies began to consider urban microclimate knowledge in planning strategies, so it can enhance user convenience. Physical development in one area can contribute to the microclimate condition. Shashua-bar (2004) has described the effects of building design such as building dimensions and building distance on the formed microclimate. Kakon (2009) also strengthens the results of his research on the influence of regional geometry on the formed microclimates, especially the impact of sky view factor on solar radiation. Shafaghat (2016) reveals how road geometry influences the formation of microclimates in one area, especially in coastal tropical climates. Microclimate is influenced by various factors including morphological characters (Kushol, 2013; Ok, 2014; Pandya, 2014), geometric patterns (Deng, 2016), construction material (Santamouris, 2012; Shishegar, 2013; Chokhachian, 2017), orientation (Shishegar, 2013; Sanusi, 2015), building density and building height (Nasira, 2016) and green space/ vegetation (Klein, 2014; Duarte, 2015).

Information about microclimate conditions gathered in one area is very useful for Planners or Architects to organize buildings and the environment. Appropriate microclimate data can help Planners/ Architects make the right decisions in climateresponsive designs, so that they can create buildings and environment to make human activities more comfortable. In addition, climate-responsive designs also have an impact on energy-efficient uses. The characteristics, as well as the form and the pattern of buildings or cities may influence the formation of microclimates, resulting in energy consumption changes (Lee, 2017). For building as an example, it occurs because the design of the building's inner space conditions also affects the energy use in the building, based on the microclimate response (Alwetaishi, 2016; Strelková, 2013; Pisello, 2015). If the microclimate condition is not appropriate, somehow, the building will respond to microclimate conditions by using electrical tools. Climate considerations in urban planning/design require detailed information/data about the changes in microclimate that occur as well as the physical environment configuration. To obtain and organize the data, several methods may be taken to provide a description of microclimate and environment condition.

Research on urban microclimate was initially carried out by observation methods such as measurements in the field. Along with the development and advancement in computing, numerical simulation approaches with modeling are becoming more popular. Direct measurement and modeling can both be used as tools to assist building and urban and design/planning in responding to climate change (Elnabawi, 2013). One of the microclimate simulation computer programs is ENVI-MET (developed by ENVI_MET GmbH), which can be used to estimate the effect of changes in climate conditions in cities (Langer, 2012). Simulation of microclimatic conditions by using ENVI-MET can present prediction results to be used in the design and planning process of buildings and cities (Elnabawi, 2013). 


\section{METHODOLOGY}

This article is the result of a research that aimed to simulate and describe the microclimate in an urban area, especially in developing trade areas. The simulation used climate data series in Pontianak City, and other required data for analysis purposes. In terms of built environment, the data were obtained directly in the field through field surveys and observations. The indicators for the data collected are as follows:

Table 1. Data Required

\begin{tabular}{ccc}
\hline No & Climate Data & Built Environment \\
\hline 1 & Temperature & Building density \\
2 & Humidity & Building orientation \\
3 & Wind speed and direction & Building material \\
4 & Solar radiation & Shadowing \\
5 & Cloud cover & Building envelope \\
6 & Soil condition & Building height \\
7 & & Vegetation \\
\hline
\end{tabular}

(Source: Several organized data, 2018)

After the data were obtained, the simulation was carried out by using the three-dimensional software ENVI_MET version 4 to see the indications/tendency in the local microclimate according to the characteristics of the built environment. The calculated microclimate element focused on the temperature conditions. The details of the research processes that had been carried out are as follows:

1. Collecting climate data in Pontianak City as well as collecting data and details on buildings and the built environment in the areas;

2. The study area is located along Gadjah Mada Street. To concise the simulation time in computer; the study areas were divided into 3 area segments (sections), divided by the characters of the building area, such as: section 1, i.e. areas with a general character of low-floor buildings, section 2 , i.e. areas with a character of having wide and tall buildings, section 3, i.e. areas with a general character of having a tall and wide building;

3. Setting the simulation parameters in ENVI_MET program. The calculation was based on the hot days/months in Pontianak City, such as (1) 23 September, (2) 21 December, (3) 21 March, and (4) 21 June 21;

4. Inputting the data into the ENVI-met program and setting the simulation parameters according to the indicators and data on the conditions that had been obtained;

5. Describing the character of the physical/built environment of the areas, such as building density, building orientation, building materials, shadowing, building envelope, building height, and vegetation;

6. Measuring/simulating the air temperature in a focused area;
7. Describing or drawing conclusions on the dominant results of the simulations, especially the high temperatures in these areas and the built environment condition surrounding the areas.

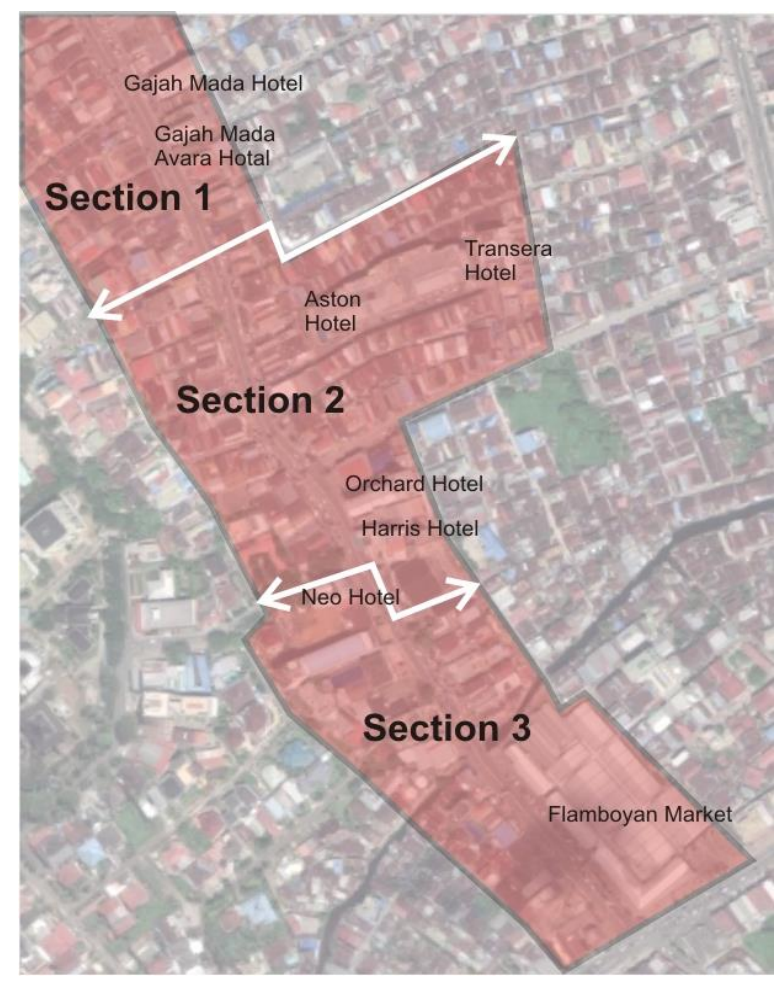

Fig. 2. Area Study (Source: Modified from Google maps, 2018)

\section{RESULTS AND DISCUSSION}

\section{Built Environment Characteristic}

This part describes the findings of the character of the built environment in the areas that may influence the microclimate condition. The aspects of the description include building density, building orientation, building materials, shadowing, building envelope, building height, and vegetation. The discussion is carried out with a description of the general tendency or dominance of the existing conditions.

\section{Built Environment Impact to Air Temperature}

In this part, described the findings of the measurement of the air temperature in the area based on the climate parameters as well as built environment characteristics. The discussion is constructed by describing the general tendency or dominance of air temperature (lowest/highest temperature and the built environment characteristics) based on the color information resulted from the simulation. Afterwards, conclusion are compiled based on the differences of air temperature against to the condition of built environment surrounding. 
Tabel 2. Data Setting in ENVI_MET

\begin{tabular}{|c|c|c|c|c|c|c|}
\hline \multicolumn{7}{|c|}{ Time and Date Output } \\
\hline 1 & Start Time & (DD.MM.YYYY) & 23.09 .2017 & 21.12.2017 & 21.03 .2018 & 21.06 .2018 \\
\hline 2 & Start Time & (HH:MM:SS) & 7:00:00 & 7:00:00 & 7:00:00 & 7:00:00 \\
\hline 3 & Total Simulation Time & (h) & 24 & 24 & 24 & 24 \\
\hline \multicolumn{7}{|c|}{ Meteorology : Basic Settings } \\
\hline \multirow[t]{4}{*}{1} & Wind uvw & & & & & \\
\hline & $\begin{array}{l}\text { Wind speed meassured in } 10 \mathrm{~m} \\
\text { height }\end{array}$ & $(\mathrm{m} / \mathrm{s})$ & 3.3 & 9.4 & 3.6 & 2.7 \\
\hline & Wind direction & (deg) & 135 & 270 & 270 & 45 \\
\hline & $\begin{array}{l}\text { Roughness length at } \\
\text { meassurement site }\end{array}$ & (m) & 0.1 & 0.1 & 0.1 & 0.1 \\
\hline \multirow[t]{2}{*}{2} & Temperature $\mathbf{T}$ & & & & & \\
\hline & $\begin{array}{l}\text { Initial temperature of } \\
\text { atmosphere }\end{array}$ & $\left({ }^{\circ} \mathrm{C}\right)$ & \multicolumn{4}{|c|}{ (use simple forcing) } \\
\hline 3 & Humidity q & & & & & \\
\hline & $\begin{array}{l}\text { Specific humidity at } 2500 \mathrm{~m} \text { top } \\
\text { of model }\end{array}$ & $(\mathrm{g} / \mathrm{kg})$ & 7.54 & 7.19 & 7.8 & 6.75 \\
\hline & Relative humidity & $(\%)$ & 86 & 82 & 89 & 77 \\
\hline \multicolumn{7}{|c|}{ Meteorology : Simple Forcing } \\
\hline \multirow[t]{5}{*}{1} & Temperature in ${ }^{\circ} \mathbf{C}$ & & & & & \\
\hline & Minimum temperature & $\left({ }^{\circ} \mathrm{C}\right)$ & 24.4 & 24.2 & 23.8 & 25.2 \\
\hline & at & (HH:MM) & 22:00 & 4:00 & 4:00 & 4:00 \\
\hline & Maximum temperature & $\left({ }^{\circ} \mathrm{C}\right)$ & 32.2 & 30.8 & 30.2 & 34 \\
\hline & at & (HH:MM) & 13:00 & 13:00 & 10:00 & 16:00 \\
\hline 2 & Relative humidity in \% & & & & & \\
\hline & Minimum Humidity & $(\%)$ & 64 & 64 & 67 & 49 \\
\hline & at & (HH:MM) & 13:00 & 13:00 & 10:00 & 16:00 \\
\hline & Maximum Humidity & $(\%)$ & 93 & 91 & 95 & 95 \\
\hline & at & (HH:MM) & 4:00 & 4:00 & 4:00 & 4:00 \\
\hline \multicolumn{7}{|c|}{ Meteorology : Further Settings } \\
\hline \multirow[t]{2}{*}{1} & Solar Radiation & & & & & \\
\hline & $\begin{array}{l}\text { Adjustment factor for solar } \\
\text { radiation }\end{array}$ & & 1 & 0.82 & 1 & 1 \\
\hline \multirow[t]{6}{*}{2} & Clouds & & & & & \\
\hline & Cover of low clouds & octas & 2.50 & 2.00 & 2.22 & 2.22 \\
\hline & Cover of medium clouds & octas & 2.50 & 2.00 & 2.22 & 2.22 \\
\hline & Cover of high clouds & octas & 2.20 & 1.83 & 2.22 & 2.00 \\
\hline & Total Cloud Coverage & octas & 7.20 & 5.83 & 6.66 & 6.44 \\
\hline & Soils And Plants & & & & & \\
\hline 1 & Initial condition for soil & & & & & \\
\hline \multirow[t]{4}{*}{ a } & Soil Wetness & & & & & \\
\hline & Upper Layer $(0$ - 20 cm) & $(\%)$ & 33.00 & 33.00 & 33.00 & 33.00 \\
\hline & Middle Layer $(20-50 \mathrm{~cm})$ & $(\%)$ & 33.00 & 33.00 & 33.00 & 33.00 \\
\hline & Deep Layer (50 - $200 \mathrm{~cm})$ & $(\%)$ & 33.00 & 33.00 & 33.00 & 33.00 \\
\hline \multirow[t]{4}{*}{$\mathrm{b}$} & Initial Temperature & & & & & \\
\hline & Upper Layer (0 - $20 \mathrm{~cm})$ & $\left({ }^{\circ} \mathrm{K}\right)$ & 293.15 & 293.15 & 293.15 & 293.15 \\
\hline & Middle Layer $(20-50 \mathrm{~cm})$ & $\left({ }^{\circ} \mathrm{K}\right)$ & 293.65 & 293.65 & 293.65 & 293.65 \\
\hline & Deep Layer (50 - 200 cm) & $\left({ }^{\circ} \mathrm{K}\right)$ & 295.35 & 295.35 & 295.35 & 295.35 \\
\hline \multirow[t]{2}{*}{2} & Settings Plant Model & & & & & \\
\hline & $\mathrm{CO} 2$ Background level & (ppm) & 410.79 & 410.79 & 410.79 & 410.79 \\
\hline
\end{tabular}

(Source: Several organized data, 2018) 
Table 3. Built/Physical Environment Characteristic

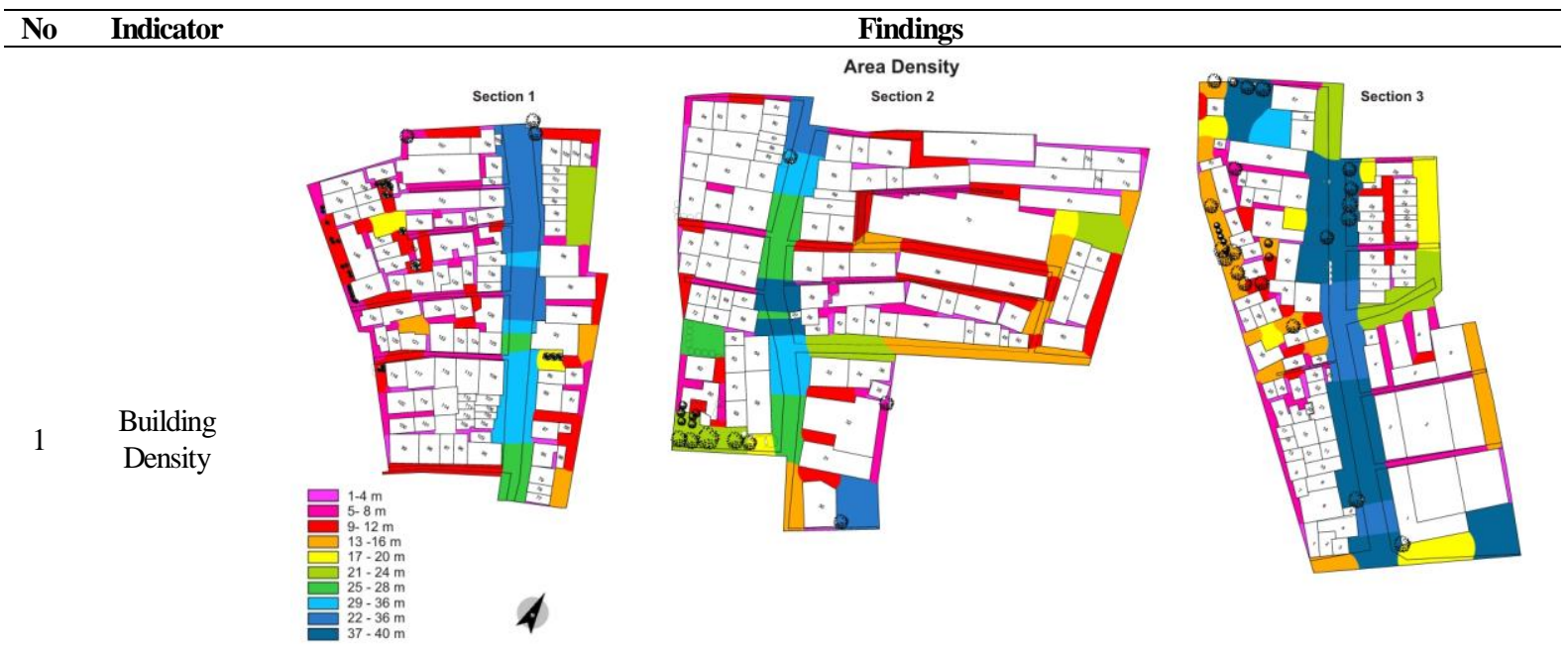

Section 1: The dominant density is at the Southwest, with a distance between buildings ranging from 1-4 meters between buildings

Section 2: The building density is equally distributed with varying distance ranging from $1-12$ meters.

Section 3: The dominant density is at the Southwest, with a distance between buildings ranging from 1-4 meters between buildings

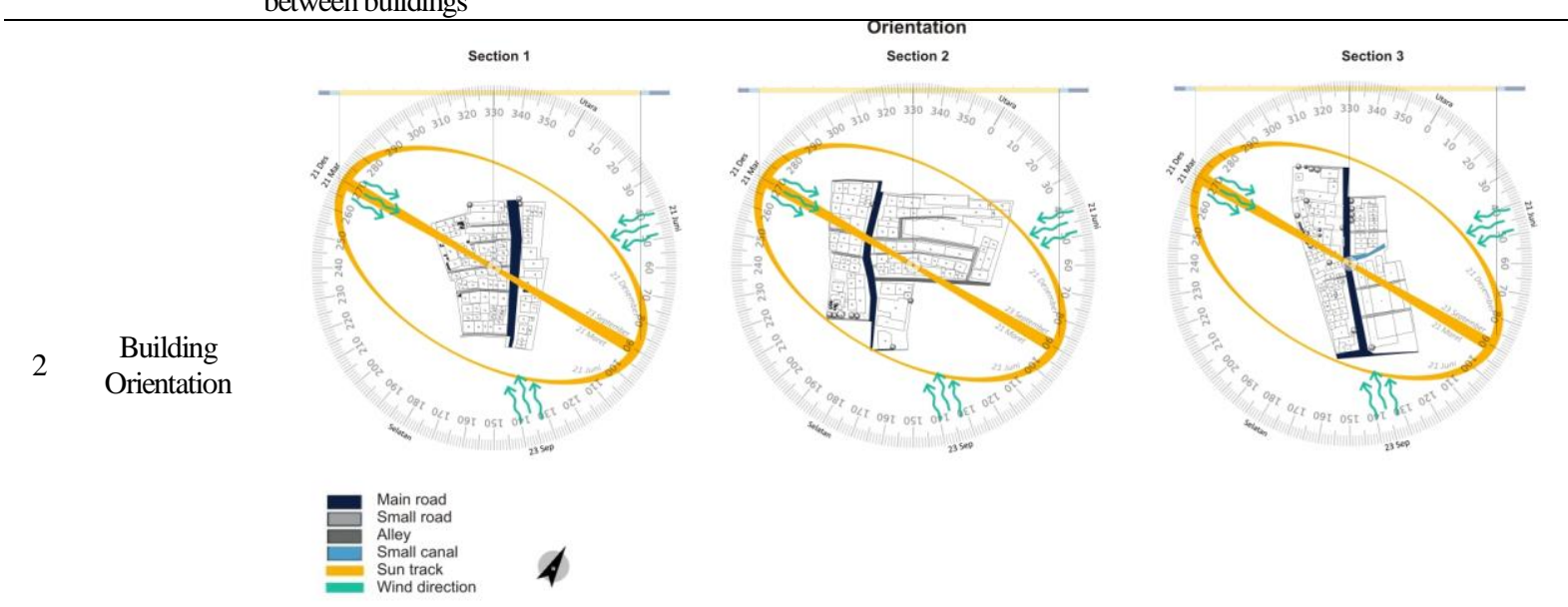

Section 1,2,3: The main street is located at the North West/Southeast. The sun track configured an angle of about 70 degrees from the main street. The wind direction is different for each study time, the wind comes from the Northeast (in June), from Southeast (in March and September), and form West (in December)

$3 \quad$ Building Material (cover)
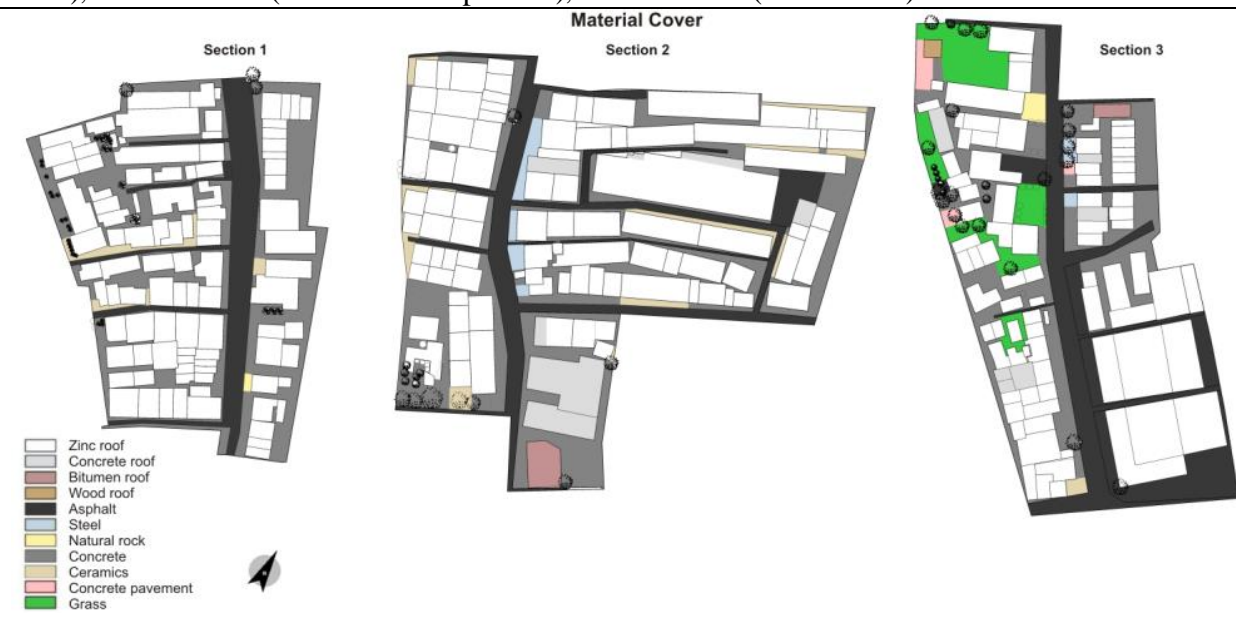

Section 1: The domination of area cover are zinc, concrete, and asphalt

Section 2: The domination of area cover are zinc, concrete, and asphalt

Section 3: The domination of area cover is zinc, concrete, and asphalt. However, there is still some green ground cover. 

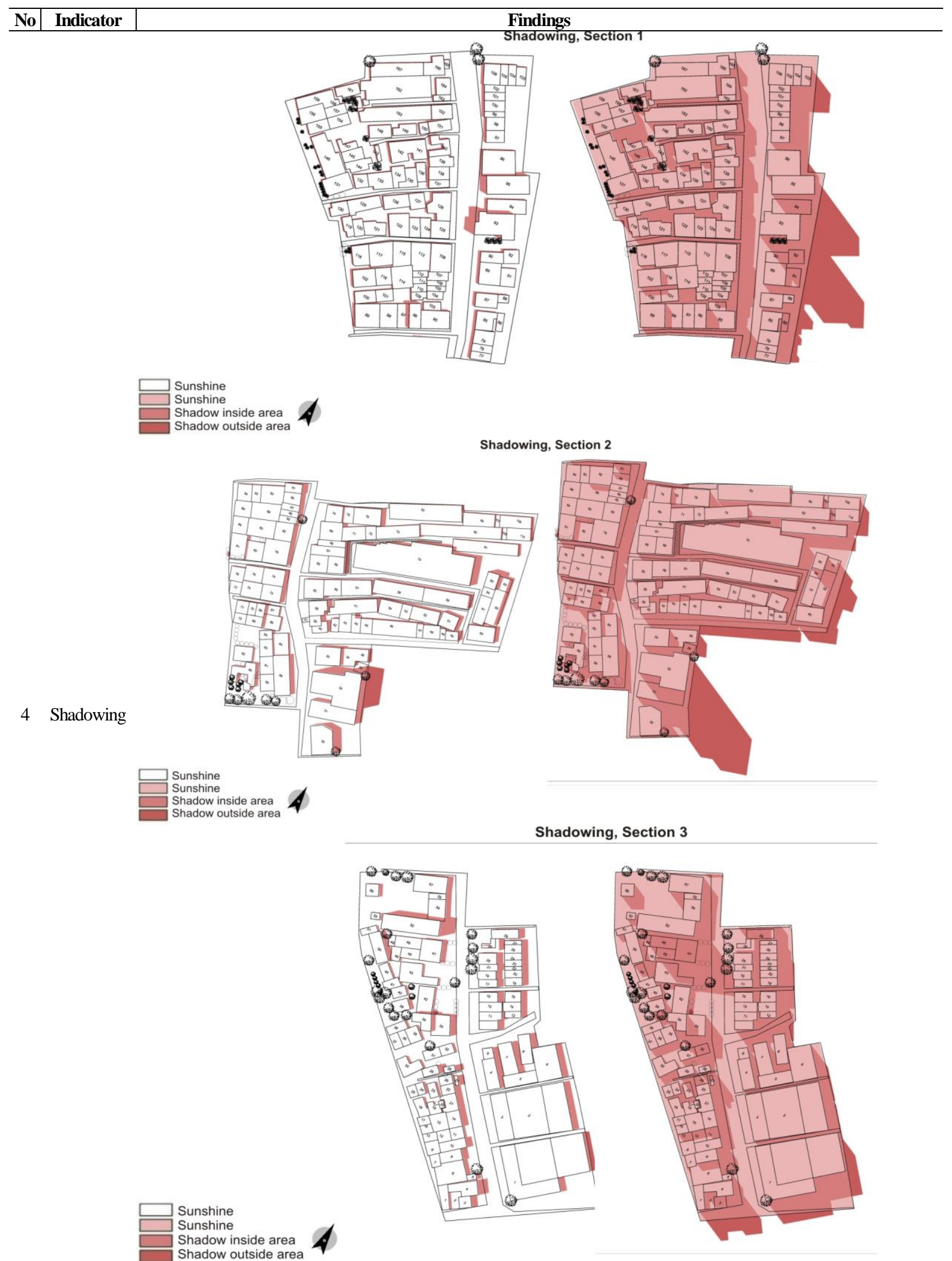

Section 1: Morning shadowing (time: 10.30) is not too extensive. In the afternoon (time: 16.30), the shadowing is extensive, especially in the Northeast

Section 2: Morning shadowing (time: 10.30 is not too extensive. In the afternoon (time: 16.30), the shadowing is extensive, especially in the Eastern

Section 3: Morning shadowing (time: 10.30 is not too extensive. In the afternoon (time: 16.30), the shadowing is extensive, especially in the Northwest 

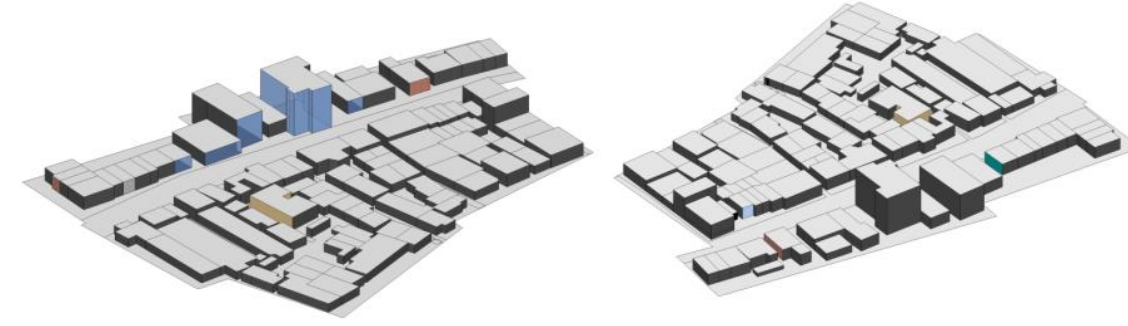

Building Envelope, Section 2
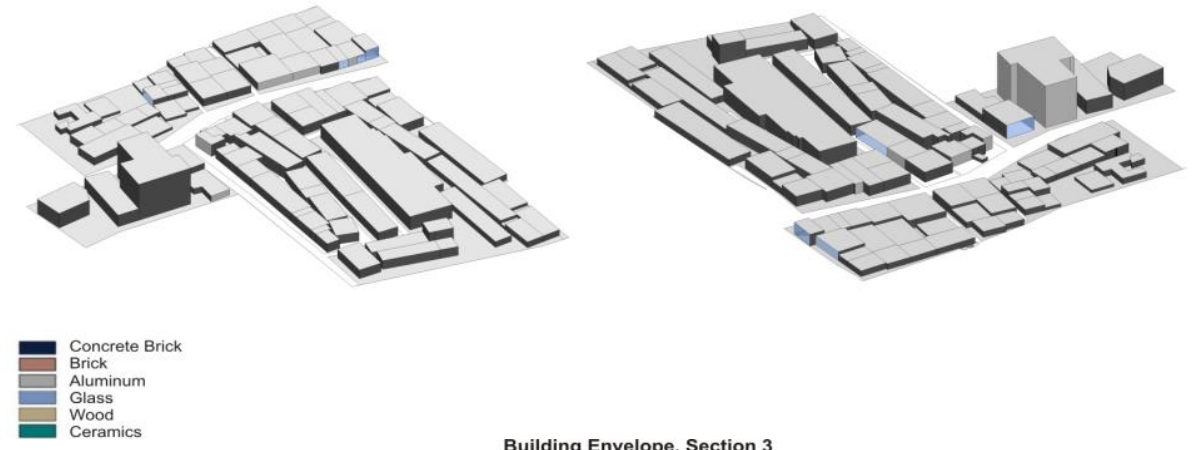

Building Envelope, Section 3
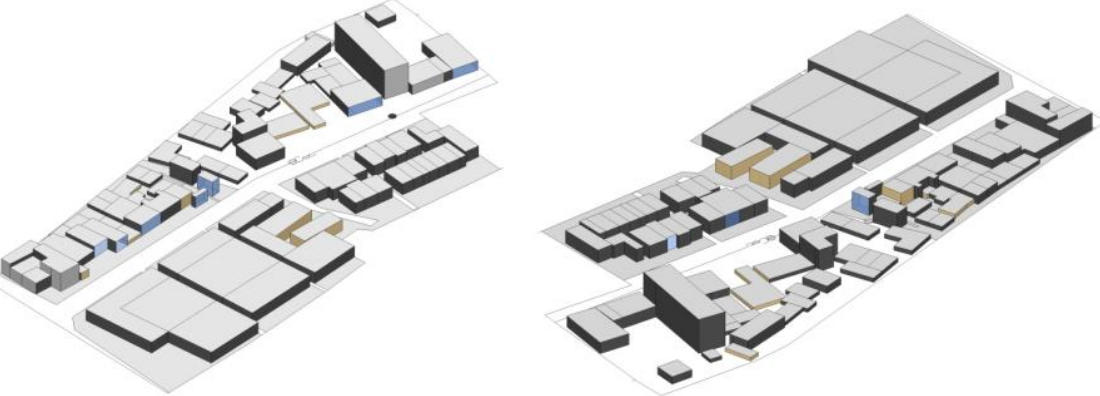

Concrete Brick

Brick

Aluminum
Glass

Wood
Ceramics

Section 1,2,3: In general, the building envelope material is dominated by brick with cement plaster. Only several buildings covered by glass, especially tall buildings

6 Building Height
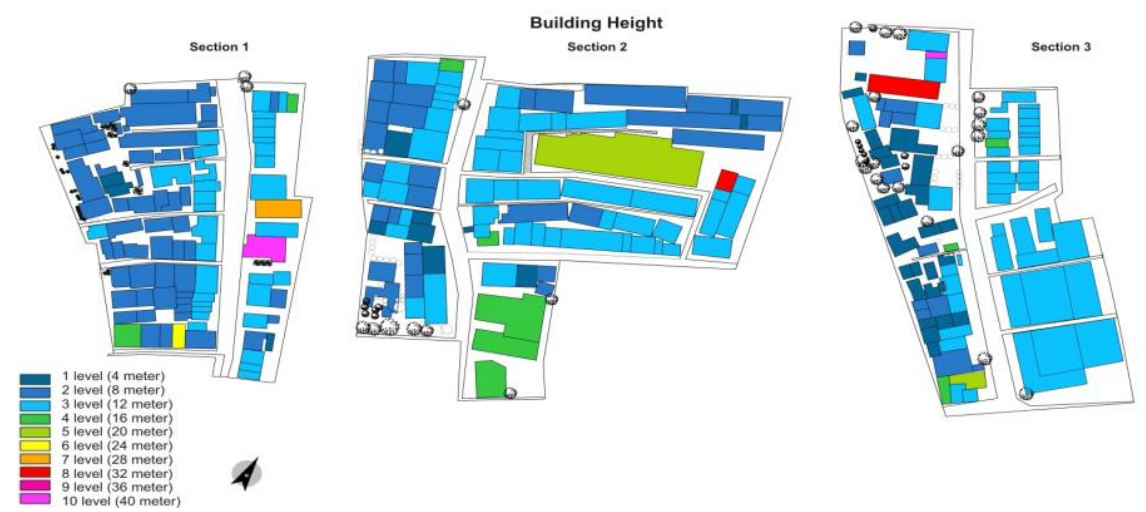

Section 1: In the dominance of a 1-2 floor building. There is one tall building

Section 2: In the dominance of a 3-5 floor building. There is one tall building and wide/ large building

Section 3: In the dominance of a 3 floors building. There are two tall building and wide/ large building 


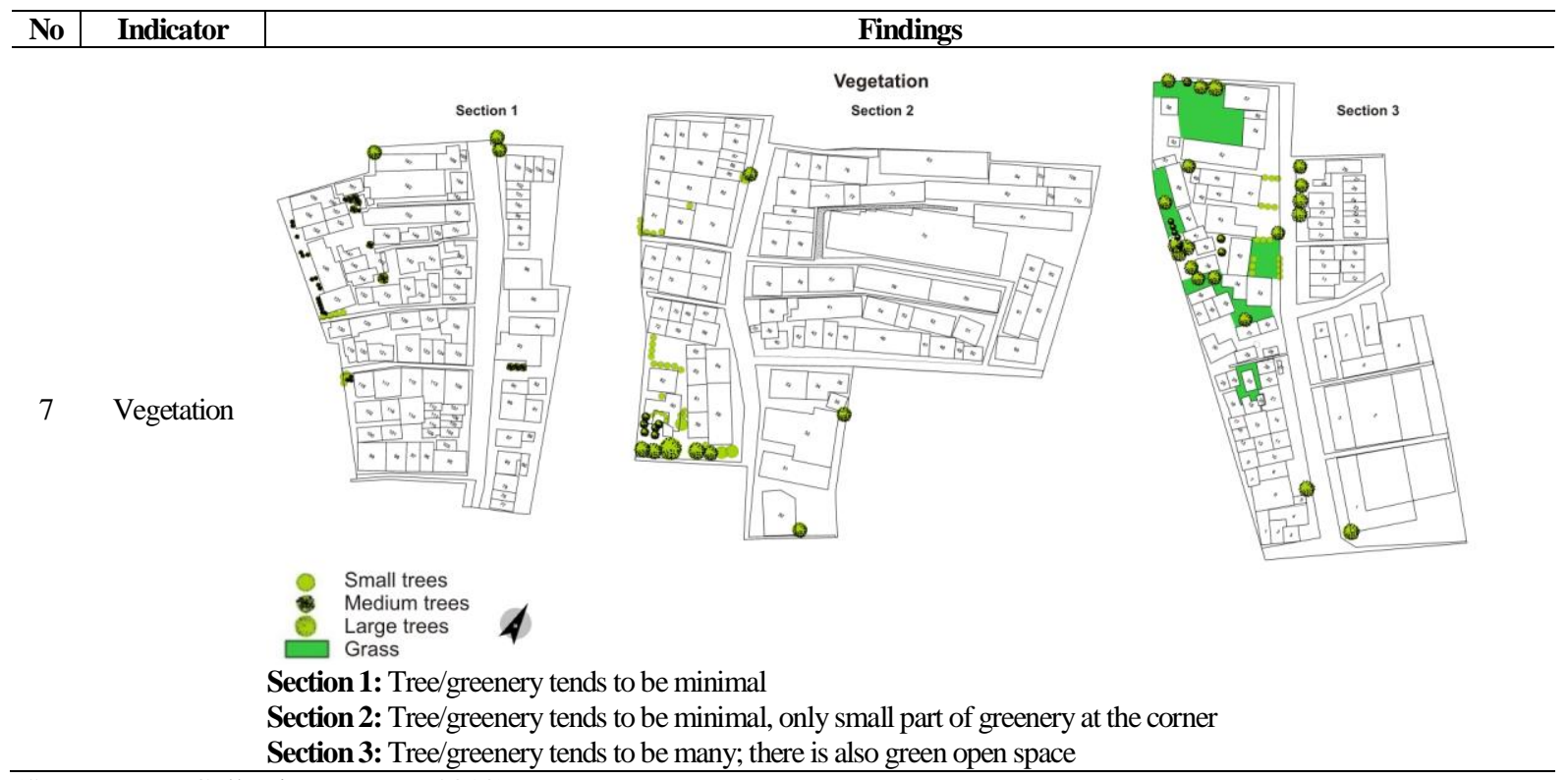

(Source: Data Collection Process, 2018)

From the comparison of changes in temperature value of the three sections above, it can be seen that March and December are the time (month) where the study areas keep the lowest temperature. The differences between the highest and the lowest temperature range of the three sections in each month are not too far, which is only around 1 degree. This shows that the hottest and the coldest areas in the study areas are not much different in temperature value. However, judging from the value of the temperature, it can be said the value to be high enough as a temperature that is comfortable for the residents. From the simulation, there is always a change in the area that experiences the highest or the lowest temperature. There are no indications that indicate one area always have the highest or the lowest temperature. In the certain month of study, the hottest/coldest areas may change along with the climate condition in the study area. This shows that atmospheric conditions or local weather has a greater influence on the temperature value. Judging from the comparison of built environment characteristics, (e.g. building height, density, sun/lighting, green area, etc.) it also does not show the specific condition of the area experiencing the highest and lowest temperatures. A certain month of study, the hottest/coldest areas may change as well.

In March (section 1), the lowest temperature is in the main road, while in section 2 it is located at a high-density area (of buildings). In contrast, in section 3 , the lowest temperature is near the green area and buildings near the main road. In June, the area with the lowest temperature in section 1 is in the highdensity area, while in section 2 located in the open space area with some vegetations. In section 3, the lowest temperature is also in the high-density area. It can be happed due to the influence of shadowing from buildings. From the condition above, however, the opposite condition occurs in section 2 . The open area, which not has the shadow from buildings, becomes the area with the lowest temperature, while in section 3, the open area which not has the shadow from buildings becomes the area with the highest temperature. In September, in section 1 and 2, the lowest temperature was in areas with high-density of building masses. However, in section 3, the lowest temperature is in the open area with some vegetation. In December, the lowest temperatures in every section are in areas with high-density of building masses

From the discussion above, the similarity of the indications on the study is the highest temperature is located at the main road (with asphalt) with lowdensity of building mass. Besides, the location of the highest/lowest temperature may be changed in certain months and tends not influences based on the characteristics of the built environment. Judging from overall indications, various characteristics of built environment influence each other; however, they do not show a dominant influence in determining the temperature of the area.

\section{CONCLUSION}

Based on the previous part of this paper, there is a relationship between the characters of the built/physical environment and the atmospheric condition or local weather. The physical development of built environment such as buildings in the context 
Table 4. Air Temperature Simulation to Built Environment Characteristics

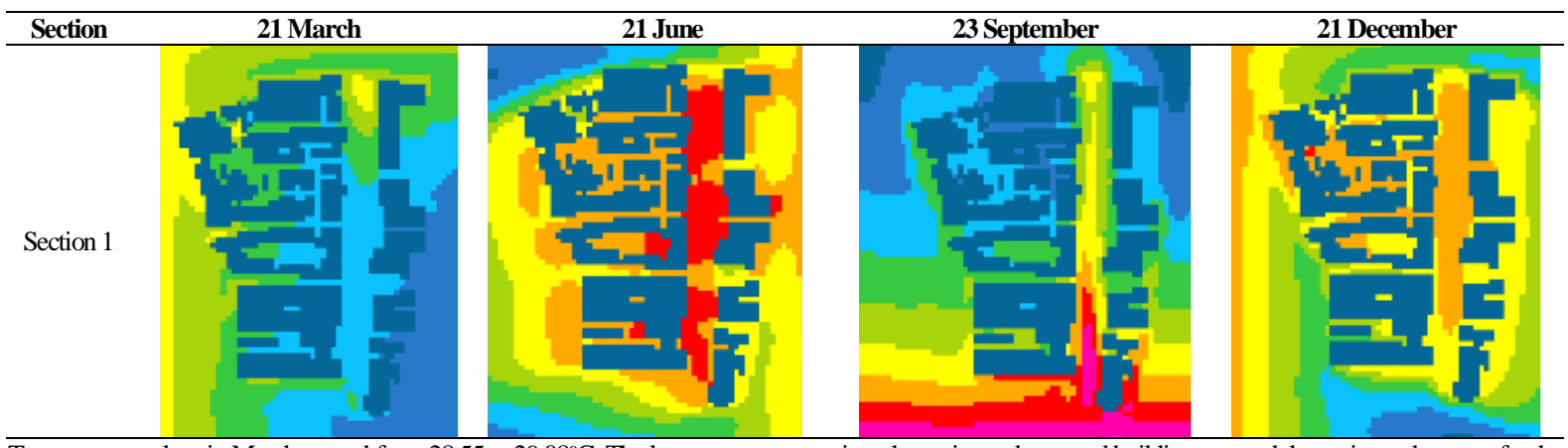

Temperature values in March ranged from 28.55 to $29.08^{\circ} \mathrm{C}$. The lowest temperature is at the main road area and buildings around the main road, except for the upper part of the main road (northwest), the temperature increases. In June, the temperature is quite high, ranging from 31.33 to $31,77^{\circ} \mathrm{C}$. Unlike the simulation situation in March, the main road temperature is the highest temperature in the area. The lowest temperature is located at the high-density (of buildings). In September, the temperature values ranged from 30.21 to $31.11^{\circ} \mathrm{C}$, showing indication similar to those that occurred in June, where the main road temperature was the highest temperature in the area. The lowest temperature is at the high-density area. In December, the temperature values ranged from 28.88 to $29.36^{\circ} \mathrm{C}$. The highest temperature value is at the main road and areas with a high-density of building mass.

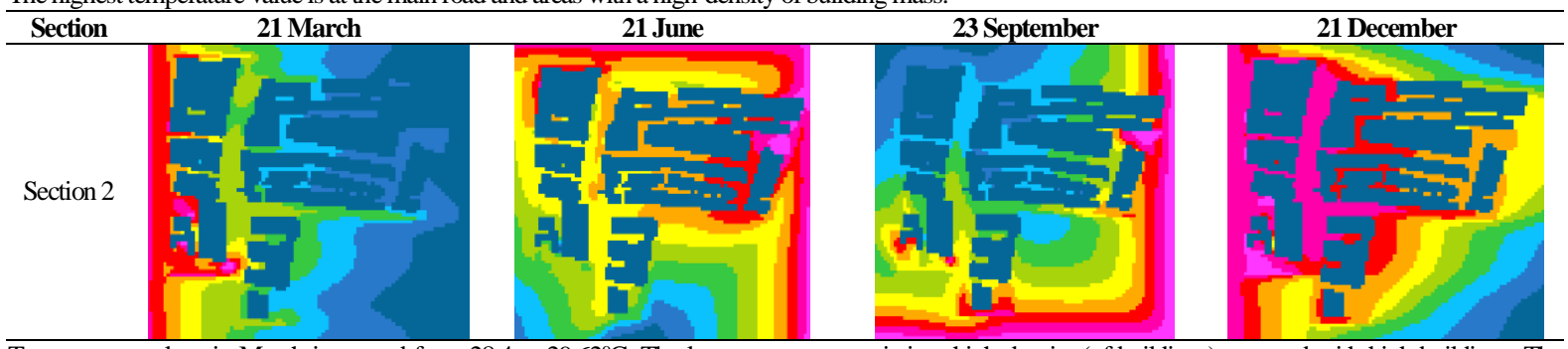

Temperature values in March in ranged from 28.4 to $29.62^{\circ} \mathrm{C}$. The lowest temperature is in a high-density (of buildings) area and with high buildings. The highest temperature is in a low-density area with several trees. In June, temperatures were quite high, ranging from 31.23 to above $31.96^{\circ} \mathrm{C}$. Unlike the simulation situation in March, the highest temperature is in the area with a high-density area and with high buildings. The lowest temperature is in a low-density area with several trees. In September, the temperature value was also quite high, ranging from 30.21 to above $31.12^{\circ} \mathrm{C}$. The highest temperature is in areas with low-density of buildings with some trees. In December, the temperature values ranged from 29.16 to above $29.53^{\circ} \mathrm{C}$. The highest temperature value is at the main road to the western part of the area (section 3). The lowest temperature is in a low-density area with high buildings

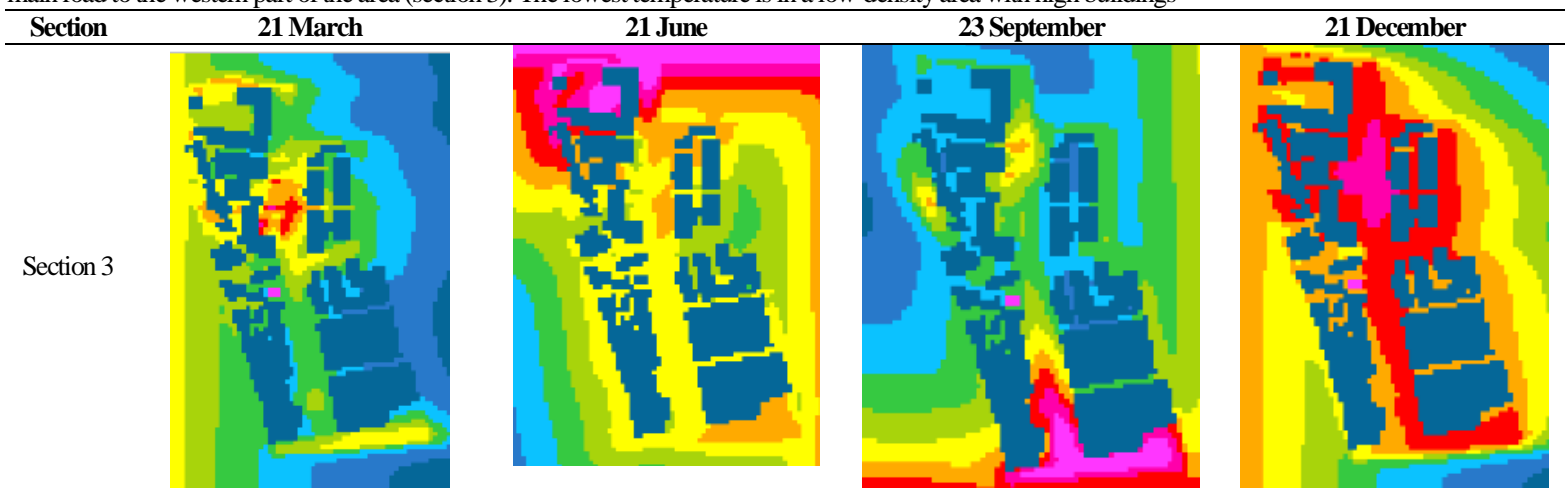

Temperature values in March in ranged from 28.65 to $29.53{ }^{\circ} \mathrm{C}$. The lowest temperature tends to be in a green open area (with some vegetation). Low temperatures are also found on the southeast part of the main road and the surrounding of the building area. In June, the temperature is quite high, ranging from 31.02 to above $31.94^{\circ} \mathrm{C}$. On the contrary, based on the simulation resulted, in June, the highest temperature is also located in the green open area. In September, the temperature value was also quite high, ranging from 30.23 to above $31.27^{\circ} \mathrm{C}$. The highest temperature is in the lower part of the main road area adjacent to the building mass with a moderate-density of buildings. In December, the temperature values ranged from 29.01 to above $29.46{ }^{\circ} \mathrm{C}$. The highest temperature value is in the area along the main road and the outer area if buildings of the upper part of the study area (section 3 )

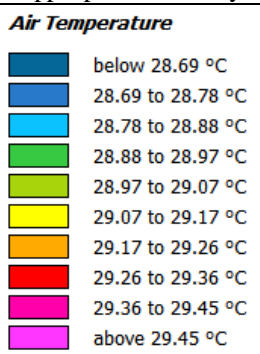


building and its environment continue to adapt to human needs. Not infrequently to fulfill those needs, massive and vertical development will be carried out. From the data collection and simulations that had been conducted, there are several findings regarding the condition of the microclimate (air temperature) with the existing built environment characters. Some notes to be considered on the indications of the different temperatures under the area simulation are:

1. Based on a certain month of study, the areas with the highest/lowest temperature may be changed. It is may indicate that atmospheric condition influences are generally still dominant rather than built environment characteristics.

2. The characteristics (condition) of the built environment are related and influence each other, but are not a dominant determinant of how area temperature is rising or falls. Several built environment elements that might affect air temperature within the study area are (1) road material (Asphalt), (2) building density and shadowing, (3) the amount of vegetation, (4) the direction of wind, and (5) distance from heat source (e.g. road material/asphalt).

The implication from the above findings is that the microclimate in the trading areas in Pontianak City can be influenced by the configuration of the built environment elements such as building density/ height, materials, etc. However, the influences of these characteristics are not a dominant, rather than the condition of its atmospheric condition.

To reduce the impact of high air temperatures due to the conditions of the built environment, the arrangement of the built or physical environment should consider the abovementioned findings by trying to provide more suitable configurations by ensuring wind access, reducing trapped areas, using environmentally friendly materials, and increasing vegetation around the area.

\section{ACKNOWLEDGMENT}

This paper is a part of research grant that was supported by Engineering Faculty, Universitas Tanjungpura Pontianak.

\section{REFERENCES}

Alwetaishi, M., and Balabel, A. (2016). Effect of Microclimates Conditions on Architectural Design of Residential Buildings in Saudi Arabia. European Journal of Advances in Engineering and Technology. 3(8): 29-32
Antara News - Economic development in Pontianak, https://kalbar.antaranews.com/berita/360326/per tumbuhan-ekonomi-pontianak-ditargetkan-610persen, accessed 2018.

Chokhachian, A. (2017). How Material Performance of Building Façade Affect Urban Microclimate. Accessed from https://www.researchgate.net/ publication/312612614, 2018.

Deng, J.Y. (2016). The Study of the Effects of Building Arrangement on Microclimate and Energy Demand of CBD in Nanjing, China. 4th International Conference on Countermeasures to Urban Heat Island (UHI), Procedia Engineering. 169: $44-54$.

Duarte, D.H.S. (2015). The impact of vegetation on urban microclimate to counterbalance built density in subtropical changing climate. Urban Climate. 14: 224-239.

Elnabawi, M. H., dkk. (2013). Use And Evaluation Of The Envi-Met Model For Two Different Urban Forms In Cairo, Egypt: Measurements And Model Simulations. 13th Conference of International Building Performance Simulation Association, Chambéry, France.

ENVI_MET - ENVI_MET Software, http://www. envi-met.com/buildings-and-climate/, accessed 2018.

Kakon, Noori, A., Nobuo, and Mishima. (2009). The Sky View Factor Effect On The Microclimate Of A City Environment: A Case Study Of Dhaka City. The seventh International Conference on Urban Climate, Yokohama, Japan.

Klein, J., and Rózová, Z. (2014). Impact of Vegetation on Microclimate in Different Layouts of Built- Up Areas in Urbanised Environment of Nitra Municipality in Spring Period. Rožnovský, J., Litschmann, T., (eds): Mendel a bioklimatologie. Brno, 3. 5.9.

Kushol, S.A.S., dkk. (2013). Effect of Street Morphology on Microclimate in Residential Areas Following FAR Rule in Dhaka City. PLEA2013 - 29th Conference, Sustainable Architecture for a Renewable Future, Munich, Germany.

Langer, I. (2012). Using the ENVI-MET program to simulate the micro climate in new Town HASHTGERD. The international conference on Computing, Networking and Digital Technologies, (SDIWC 2012), S. 61-64.

Lee, G., and Jeong, Y. (2017). Impact of Urban and Building Form and Microclimate on the Energy Consumption of Buildings - Based on Statistical Analysis. Journal of Asian Architecture and Building Engineering. 16(3): 565- 572. 
Nasira, D. SNM. et al. (2016). Effect of Urban Street Canyon Aspect Ratio on Thermal Performance of Road Pavement Solar Collectors (RPSC). The 8th International Conference on Applied Energy.

Ok, V. et al. (2014). Effects of Urban Structure To Microclimatic Conditions In Hotdry Climatic Zone; A Case Study in MARDIN Enes Yasa. Accessed from https://www.researchgate.net/ publication/320002903., 2018.

Pandya, S.V., and Brotas, L. (2014). Tall Buildings and the Urban Microclimate in the City of London. 30th International Plea Conference, CEPT University, Ahmedabad.

Pisello, A.L. (2015). The Impact of Local Microclimate Boundary Conditions on Building Energy Performance. Sustainability. 7, 92079230; doi: 10.3390/su7079207.

Pontianak City Statistical Agency - Statistical Data, https://pontianakkota.bps.go.id/, accessed 2018

Santamouris, M. et al. (2012). Using Cool Paving Materials to Improve Microclimate of Urban Areas - Design Realisation and Results of the Flisvos Project. Building and Environment. 53: 128-136.

Sanusi, R. et al. (2015). Street Orientation and Side of the Street Greatly Influence the Microclimatic Benefits Street Trees Can Provide in Summer. Journal of Environmental Quality.
Shafaghat, A. et al. (2016). Street Geometry Factors Influence Urban Microclimate In Tropical Coastal Cities: A Review. Environmental and Climate Technologies.

Shashua-bar, 1., Tzamir, Y., and Hoffman, M.E. (2004). Thermal Effects of Building Geometry and Spacing on the Urban Canopy Layer Microclimate in a Hot-Humid Climate in Summer. International Journal of Climatology. 24: 1729-1742.

Shishegar, N. (2013). Street Design and Urban Microclimate: Analyzing the Effects of Street Geometry and Orientation on Airflow and Solar Access in Urban Canyons. Journal of Clean Energy Technologies, 1(1).

Strelková, M. (2013). Influence Of Vegetation On Microclimate In The Urban Environment. Folia Oecologica, 40(2).

Suara Pemred Kalbar - The development of Hotel in Pontianak, http://www.suarapemredkalbar.com/ berita/ponticity/2018/01/22/pertumbuhan-hotelstagnan-pontianak-miliki-4160-kamar, accessed 2018.

Thetanjungpuratimes - Traditional Markets are getting Stuck, http://thetanjungpuratimes.com/ 2016/02/22/pasar-tradisional-makin-terjepit/, accessed 2018. 